\title{
The Role of Indigenous Films in Preserving Nigerian Culture: Analysis of Efunsetan Aniwura
}

\author{
Morolake Dairo \\ School of Media and Communication, Pan-Atlantic University, Main Campus, \\ Km 52 Lekki - Epe Expressway, Lagos, Nigeria
}

\begin{abstract}
Film is a powerful medium that can be used in transmitting different ideologies and preserving cultural values. In the western world, films have been used to strategically positioning foreign culture and selling it subtly on a global scale to other nations who eventually adopt western cultural values. This research investigates the role of film as a medium of preserving and promoting the appreciation of the Nigerian culture locally and globally through the exploration of historical events and local cultures. The methodological framework adopts a qualitative approach, using content analysis in investigating the film, Efunsetan Aniwura. Findings from this research show that films are an effective medium for preserving and transmitting cultural values. It is necessary for the government and stakeholders of the Nigerian film industry to continuously partner in creating and promoting content that educates locals and foreigners about Nigerian culture for the sake of cultural appreciation and posterity.
\end{abstract}

Keywords: Nigerian culture, Indigenous films, Yoruba culture, Efunsetan Aniwura

DOI: $10.7176 / \mathrm{JCSD} / 65-03$

Publication date:July $31^{\text {st }} 2021$

\section{Introduction}

Globalization has opened the doors to the proliferation and exchange of culture locally and internationally and films have been one of such tools instrumental to the spread of these cultural values. The cultural heritage of any nation symbolizes the history and legacy of the nation's values and artefacts transmitted from one generation to another for cultural longevity. These values include arts, customs, festivals, sacred or worship sites, values, clothing, ways of eating, architecture, spiritual and political structures (Hasibuan, K.Isal, N.C., Ahmad, \& Selviandro, 2011; Onyima, 2016).

History reveals that oral and written traditions were the main forms of preserving culture for the next generation in human societies (Baecker, 1997; Johnson, 2013). Onyima (2016) describes these ancient cultural preservation techniques as a "body of information" comprising of a people's history, experiences, cultural background and environment at a certain time, mentally stored and conveyed verbally in form of traditional proverbs, tales, performances include song and dance, riddles, incantations, praise songs, poems amongst other means. In recent times, these bodies of information have since been packaged and preserved for future generations in documentaries, films, books, songs, and digital experiences.

However, as globalization and modernization continue to permeate societies and communities with the aid of digital technology, various aspects of the Nigerian culture including its social institutions are on the verge of extinction. Mimicking other cultures, rather than embracing and celebrating our cultural histories can lead to the loss of our cultural values systems (Onyima, 2016). The inherent dangers are fatal to the cultural existence of a society as the dearth of cultural values will eventually lead to the extinction of society and erosion of cultural values, a major component of what distinguishes other nations, communities and societies from others.

Already, there is a threat to indigenous language (Dalton, 2016)s in Nigeria with the adoption of English as the first language of the country, languages such as Yoruba and Igbo are on the decline, and are no longer compulsory subjects in Nigerian secondary school syllabuses (Ani, 2012; Olajoke \& Oluwapelumi, 2018). While cultural dress forms are evident during events such as wedding ceremonies in Nigeria, most corporate institutions have adopted the westernized dress code for employees (Olaoye \& Bello, 2016), suits and dresses have been embraced despite the humid weather conditions in the country.

Apart from government policies and actions, entertainment has been used in changing and framing perceptions about social issues (Tsebee, 2011). Films such as Malcolm X, Selma and The Help take you on a trip down the past to explore topics of racism. Others such as King of Boys and Moana explores $21^{\text {st }}$-century movements such as feminism and women empowerment, while Bend It Like Beckham and UpNorth explore cultural differences and compromises. This paper explores how films in particular can be used as tools of cultural education and preservation. Already, the Nigerian film industry, Nollywood is pulling its weight with historical movies like Saworoide, '76 and Invasion 1897 which explore key historical moments in Nigeria (Dalton, 2016; Olaiya, 2020; Omoera, 2015).

Even as cultures evolve, it is important to draw lessons and insight from the past to move forward within a society. As much as there are some unethical traditional practices such as the killing of twins or female 
circumcision, some others like folktales and proverbs still prove useful and relevant in current times. This study seeks to determine the role of indigenous films in promoting and preserving Nigerian culture by analyzing the cultural values and elements used in films. Efunsetan Aniwura is the film chosen as the case study for this research, an autobiographical movie on one of the female legends and leaders in Yoruba history.

\section{Literature Review}

In the pre-colonial times, the preservation of Nigerian culture was dependent on the political and spiritual structure in societies as aspects of culture including oral traditions and physical artefacts were stored in royal palaces, sacred grooves and human guardians. These guardians of cultural heritage included traditional rulers, chiefs, kings, priests and families who passed knowledge and skills down to the next generation. Cultural activities such as beading, sculpting, cloth weaving were family occupations inherited by a younger generation mentored by older ones (Onyima, 2016). However, colonialism resulted in cultural domination with English becoming the predominant language in Nigeria, while British ways of life were adopted by Nigerians (Agbanusi, 2017; Onyima, 2016).

The mass media contributed to the spread of these new cultures, and books and films were used to spread the propaganda of a new way of living. The mass media continues to play an important role even in the $21^{\text {st }}$ century, where digital technology and globalization have turned the world into one large village with no boundaries. Films have been used to spread and preserve cultural histories and activities that face the danger of extinction (Maisuwong, 2012; Showkat, 2017; Weinstein, 2001). Already, films from Nollywood are exporting Nigerian stories to the world, but there is the need to tell more Nigerian stories that are culturally focused on the diversity and history of its citizens. A look at the foreign film industry like Hollywood will reveal a painstaking effort to constantly expose positive aspects of their culture, cities and ideologies through their storylines and imagery (Balabantaray, 2020; Enahora, 1989). The imagery and stories in these Western movies have shaped the perception of their cities and way of life. This paper focuses mainly on how the audio-visual features of films can contribute to the preservation of Nigerian culture.

\subsection{The Role of Film in the Society}

In the era of globalization, films have become a tool of cultural transmission. Supported by online streaming platforms such as Youtube, audio-visual content is becoming readily available to individuals across the world. While globalization brings diverse people from all races together, there is the danger of emphasizing Western cultural values as dominant and most preferred. Even with the promulgation of the Nigerian Enterprise decree in 1972 by the Federal Military government to shrink foreign interests in certain economic activities in Nigeria, hence allowing distribution and exhibition of feature films to Nigerians - the content of a majority of indigenous films still shift towards the reflection of foreign cultures rather than Nigerian cultural values (Enahora, 1989). Cultural imperialism is on the increase and movies are vehicles of global as reflected in the proliferation of western films which leads to the propagation of foreign cultures in preference to Nigerian culture.

There is a need to constantly tell the African story and preserve these histories and culture, while western super-heroes such as Thor, Black Panther, Aqua Man, Wonder Woman and Superman are well accepted in Africa, African characters such as Sango, Oya, Mami Wata, Oduduwa and Anubis seem to be downplayed and less celebrated. There is an opportunity for filmmakers to promote such African stories locally and internationally, as films are powerful tools that can promote various ideologies within selected communities. As vehicles of communication films, transport stories and ideas to the audience and can shape global perception on cultural elements such as dressing and language (Sherak, 2011).

Films also act as conveyors of history; they allow the audience to experience past events. For example, the Nigerian-produced movie, " 76 is a historical fiction directed by Izu Ojukwu, that dramatizes the assassination of General Murtala Mohammed and a coup that happened in 1976. In addition to history books, such films give the viewer a visual perspective of the political and social history of Nigeria in the 1970s and can help in the appreciation of Nigeria's political history (76 The Movie, 2015).

Films also play a descriptive role in the exploration of global societies and culture and have been used to educate others about world culture while dispelling cultural misconceptions (Teutsch, 1995; Oza, 2021). The movie, Wedding Party directed by Kemi Adetiba and released in 2016 is based on the wedding ceremony between two major ethnic groups, the Igbo and Yoruba in Nigeria and it showcases the culture of some of these groups in Nigeria by focusing on the language, dance, and food amongst other cultural values. Another example is, Oleku, a Nigerian movie produced in 1997 by Tunde Kelani that sparked a fashion revolution home and abroad with the prominent use of the female Yoruba traditional wear, Iro and Buba, a wrapper and blouse ensemble (Afolabi, 2011; Izuzu, 2016). The American movie, Coming to America produced in 1988 is another cinematic example that explains cultural diversity through its thematic plot by showcasing the difference between the cultural values in the homeland of an African prince and the American way of life (Akinseye, 2017; Mckenzie, 2018). With the support of plot, characterization, soundtracks, costume, settings, narration, lighting, 
camera angles, and other cinematic elements, films have been used to convey and emphasize cultural meanings in films.

\subsection{The Culture of the Yoruba People}

The culture of the "Yorubas' (an ethnic group located mostly in the western region of Nigeria) forms the empirical reference for this study and is inclusive of their way of dressing, greeting, language amongst other cultural elements unique to the Yorubas. Various historical constructions trace the origin of Yoruba people to Ile Ife, a city in Osun State which has been referred to as the cradle of Yoruba land and the origin of all human life. Others have claimed that Yorubas are from Arabia (Agai, 2021; Akintoye, 2014; Alao, 2017).

While migration and globalization have resulted in cultural expansion, Yorubas are mostly located in the South-Western region of Nigeria and speak the Yoruba language (Oti \& Ayeni, 2013). Depending on the location and sub-groups, Yoruba people speak various dialects, for example, the Ijeshas speak Yoruba Ijesha, while the Ijebus speak in their Ijebu dialect (Agai, 2015). The Yorubas are also popular for their greetings which are tailored to suit almost any occasion or event, and their values for respect is evident in these greetings. In addition to this, Yorubas are popular for their use of proverbs in accentuating their discourse (Osoba, 2014). However, some of these traditions are being lost in translation and the adoption of foreign languages and cultures.

In terms of clothing, the Yorubas are still popular for the Iro, Buba and Gele (traditional blouse, wrapper and head tie) garb usually worn by the females while the Fila, Agbada and Sokoto (traditional cap, top and trousers) are worn by the men (Ademuleya, 2017; (Olowookere, 2016)). In modern times, such traditional clothing remains relevant for events, festivals and daily activities and these styles have been adapted and reconstructed to reflect modern cuts, styles, resulting in a hybrid of "trad-modern" styles.

The political structure of the Yoruba people in the pre-colonial era usually includes a male monarch, the Oba who is supported by a council of elders and chiefs. Some other communities, such as is evident in the film used for this study, Efunsetan Aniwura (Oti \& Ayeni, 2013), have political heads, such as the Aare elected by the chiefs who select leaders based on the people's choices. As this study revolves around the female historical figure, Efunsetan Aniwura, it is important to note that the political structure in pre-modern Yorubaland accommodated the role of women in government with women conferred chieftaincy titles such as Iyalode which can be translated as the prominent female chief or head of women in the Yoruba society (Adeeko, 2017).

\subsection{Character Summary of the Second Iyalode of Ibadan, Efunsetan Aniwura}

Historically, Efunsetan Aniwura is known as the second Iyalode (high ranking female chieftain) of Ibadan, holding the title from 1867 - 1874. She is described as a fearsome, wealthy farmer (as synonymous with her name, Aniwura translated as wealthy one) and slave-owner who traded with the Europeans and imported arms and ammunition; lending some to warriors during wars which she may have also participated in. Her influence and involvement in arms dealing contributed to her participation in political affairs in Ibadan, an ancient city in Nigeria (Akanji \& Dada, 2012). Her downfall is attributed to her discord with the leader of Ibadan, Aare Latoosa, a powerful warrior and general who frequently rented arms and ammunition from Efunsetan. Some historical accounts (Akanji \& Dada, 2012) relate that his inability to repay his debt promptly led to Efunsetan ceasing to borrow Latoosa, weapons for his next battle. In the 1800s, within the Yoruba society, women were viewed as the "weaker sex" and a wealthy woman like Efunsetan would have been a threat to Latoosa's rule and a patriarchal society.

Osewa (2005) as cited by Akanji \& Dada, (2012) quotes one of the praise songs describing Efunsetan thus;

Efunsetan, Iyalode. One who has horses and rides them not. The child, who walks in a graceful fashion. The great hefty woman who adorns her legs with beads; whose possession surpasses those of the Aare. Owner of several puny slaves in the market. One who has bullets and gunpowder, who has gunpowder as well as guns; and spends money like a conjurer. The Iyalode who instils fear into her equals. The rich never give their money to the poor. The Iyalode never gave her wrappers to the lazy.

In the film, analysed for this paper and in several historical accounts (Adeeko, 2017; Ilesanmi, 2014)., Efunsetan's generous and cheerful persona suffers a tragic decline, when she loses her only child during childbirth and blames God for her loss. Eventually, she becomes cruel to her slaves and makes an order that any slave who gets pregnant will be killed. Her attitude towards her slaves and neighbours is used as a justification by Latoosa to plot her murder. Some accounts attribute the death of Efunsetan, to suicide in her bid to prevent her capture and humiliation by the Chiefs in the city and some other accounts attribute her death to a murder plot by Latoosa and some of her relatives (Adeeko, 2017; Ilesanmi, 2014).

\subsection{Summary of the Film, Efunsetan Aniwura (2005)}

Efunsetan Aniwura was produced by Tunde Kelani in 2005 and is adapted from the eponymous novel written by Professor Akinwunmi Ishola originally written in Yoruba and translated to English (Adeeko, 2017). The film produced in 2005 is a remake of the previous version shot on celluloid by movie producer and director, late 
Ishola Ogunshola in the 80s' and the major characters in the movie, Samson Eluwole and Iyabo Ogunsola were recast in the 2005 adaptation to play their previous roles as Latoosa and Efunsetan. Since then, other versions of the film have been produced by others. This film gives a historical outlook around the character and position of Efunsetan Aniwura as the second Iyalode of Ibadan and chronicles her reign in this position detailing her power as a wealthy woman who owned a lot of slaves and supported the Ibadan army with ammunition and arms, as time passes Efunsetan and the principal ruler of Ibadan, Aare Latoosa fall apart when she refuses to support and respect his political office (Adeoye, 2016; Odejimi, 2018).

Her generous persona is transformed and regresses when she loses her only child and daughter, Toyosi, during childbirth. After this tragedy, she bans her slaves from getting pregnant. Eventually, two of her slaves; Itawuyi and Adetutu fall in love and eventually, Adetutu gets pregnant. In accordance with her pregnancy ban, Efunsetan beheads Adetutu. Itawuyi plans his revenge and attempts to poison Efunsetan, but her supernatural powers are revealed when she mysteriously uncovers his plan. She continues mistreating her slaves until it becomes a national issue leading to the interference of Aare Latoosa who orders her on an exile based on her ruthless treatment of slaves. The film ends with Efunsetan committing suicide before she is captured and disgraced.

The film Efunsetan Aniwura was chosen because of its historical origins and the era in which the movie was set, which helps to give the viewers an idea of the cultural nuances of the Yoruba society in the $1800 \mathrm{~s}$. The focus on the female character, Efunsetan, also helps to understand the political power play and the place of gender in a patriarchal society. This paper is limited to the study of tangible and intangible culture exhibited in the movie such as clothing, eating methods, language, dance and music and will not focus on character analysis.

\section{Methodology and Data Analysis}

This study adopts the qualitative research method in exploring the key variables within this study. The content analysis method was used in examining the film, Efunsetan Aniwura to explore the cultural elements specific to the film. This film was watched online repeatedly on YouTube, as the compact disc version was unavailable for purchase and it appears it currently out of circulation. The content was analysed for the cultural elements showcased in the movie. The film was paused intermittently to allow the researcher to take notes. The film focused on the major character, Efunsetan but includes other supporting characters such as Aare Latoosa, Itawuyi, Adetutu and Awero. The following elements related to the tangible and intangible culture of the Yoruba people were analyzed, language, style of greeting, music, clothing, proverbs amongst other elements.

\section{Results \& Discussions}

This section addresses the analysis of the cultural elements observed from the movie, Efunsetan Aniwura. The film starts with a narration on the city of Ibadan and the feats of its warriors; the narrator extols notable past male and female personalities of Yorubaland; Iba Oluyole, Balogun Ibikunle, Basorun Ogunmola, Aare Latoosa, Omosa, Iya Ofa and Efunsetan Aniwura giving the audience a historical view of Ibadan, a city central to Yoruba history. Such information is rarely available in textbooks and an audio-visual representation supported with English subtitles enriches the audience with historical information on the city of Ibadan.

In the subsequent sections, the cultural elements observed and analysed in this movie will be discussed.

\subsection{Means of Communication}

The Yoruba language was used all through the film and accompanied by English subtitles. This is in tune with the era and the times in the 1800s before colonial rule. Language is a key part of the culture and it ushers the audience into the Yoruba way of speaking from the beginning of the movie to the end. Also, another cultural element synonymous with the Yoruba language is the use of proverbs which was predominantly used in conversations amongst characters. Towards the end of the movie, Latoosa Aare Onakakanfo and Efunsetan exchange words using proverbs to support their discourse. Channels of communication are also affiliated with language and in communicating, in one of the scenes, a messenger in the palace was the mouthpiece of the King and usually delivered messages as there were no electronic means. This communication occurred in the market square, which signifies a meeting point for communal discussions. The death of Adetutu is revealed in the open square by one of the market women to the rest of the people, depicting a traditional means of spreading information in the community.

\subsection{Style of Greeting}

Another cultural element evident in the film is the style of greeting observed, respect for status, hierarchy and age are displayed in the greeting styles of the actors and actresses; women genuflected while the men prostrated with their hands on the floor as synonymous with traditional Yoruba greeting styles. In the $21^{\text {st }}$ century, these greeting styles have since evolved to adapted styles of genuflection and semi-prostrations or a slight bow of the head depending on the situation and setting. 


\subsection{Eating styles}

Some of the scenes in the movie included eating and no cutleries were observed in the scenes that involved actors eating, the local food was eaten by hand and water was served in a small calabash. This is still a type of eating style in Nigeria and amongst Yoruba people especially for solid meals referred to as swallow such as Amala (Yam flour|) or Eba (Cassava flour) eaten with traditional soups.

\subsection{Music}

Praise singing is a popular culture amongst the Yorubas even in the $21^{\text {st }}$ century and this is evident in the film. In a scene, announcing the entrance of Efunsetan Aniwura, some drummers used the talking drum to sing her praises as the "the peacock...Queen of birds." Music is also evident as a means of communication when the praise singer sings of the feat and persona of Aare Latoosa and describes him as "an elephant of a man" and a powerful unconquerable warrior and a master of war. Singing was also used by Adetutu to express her fear of beheading by Efunsetan Aniwura. In another scene, celebrating the birth of twins in the town, people of the town sang in celebration of their birth as in ancient times, twins are believed to be magical beings (Leroy, OlaleyeOruene, Koeppen-Schomeru, \& Bryan, 2002). This shows that music is used to communicate woes, joys and status amongst the Yoruba people (Carter-Enyi, 2018).

\subsection{Dressing}

Garb is a key signifier of culture and this was evident in this film. Most of the actors and actresses were clothed in Aso-oke, a traditionally woven fabric popular amongst the Yoruba people (Olutayo \& Akanle, 2009). Clothing is used in the film to communicate wealth and status, wealthier women wore the traditional Yoruba top, wrapper and scarf, known as the Iro, Buba and Gele respectively, with the wrapper tied to their chest, while the slaves wore only wrappers tied to their chest without any top. Compared to women of lesser status, Efunsetan had her neck adorned in coral beads with matching earrings and coral beads on her ankles depicting her wealth and title as a Yoruba female leader. Clothing and accessories were used to show the difference in status and socioeconomic willpower. Chiefs of the palace were also regally dressed in traditional caps known as Fila and Yoruba traditional male wear consisting of traditional shirt and trousers known as the Agbada and Sokoto, coupled with coral beads on their hands and necks. Hairstyles for the women revealed woven hair and there is a further distinction between the slaves and the freed as all the female slaves do not wear scarves as hair covering like the freed females. However, the outfit of the executioner in the scene showing the death of the slave Adetutu was made of a lightweight fabric which can be regarded as modern clothing and it seemed inconsistent with the era portrayed in the movie. Efforts were made to research such clothing related to that era, but no research was found to justify this choice as of the date of this study.

\subsection{Ceremonies and Events}

The Yoruba ethnic group is also well known for their cultural events such as naming and wedding ceremonies and this was evident in the movie Efunsetan Aniwura. Compared to modern-day childbirth which involves hospitals, an old woman acted as the midwife with other women to support Toyosi, Efunsetan's child, during her ill-fated childbirth. In the funeral ceremony held in honour of Toyosi; $a$ coffin was absent, rather the body of the deceased Toyosi was fully wrapped in white and transported by men amidst a mourning crowd. The mother of the deceased was dressed in dark clothing without her usual jewellery and expensive clothing showing that clothing is a significant component used to express mourning amongst the Yoruba people and is a key element in communicating ceremonial themes and emotions.

\subsection{Political Structure}

This film was centred around the political tussle between Efunsetan and Aare Latoosa. Hence, the political structure was worth observing and the analysis revealed a political structure that supported the delegation of power by a supreme head, Aare Latoosa who led with the support of subordinate chiefs that acted as political checks and balances as well as advisors. The power structure was evident in making decisions concerning Efunsetans' fate after the murder of her slaves. It also revealed the position of women in government in that era, as only one female, Efunsetan Aniwura was amongst the ruling chiefs.

\section{Conclusion}

The film provided a retrospective look at the cultural values in Yoruba land in the $1800 \mathrm{~s}$, values and elements that are fast becoming substituted with western cultural values. Archiving such cultural elements and histories through an audio-visual medium such as film help to preserve cultural elements and can be used for educational purposes. The Nigerian film industry plays a huge role in exporting our culture and preserving our culture for cultural preservation and longevity. Stories such as Efunsetan Aniwura must have films to suit various age groups and eras, ensuring the Nigerian culture remains intact and relevant for centuries to come. During this 
research, some movies similar to Efunsetan Aniwura such as Sango and Saworoide were unavailable in form of compact discs or online as of the time of this study. Hence, practitioners in the Nigerian film industry should look into the preservation and digital restoration of such movies as well as invest in the remake of historical movies to ensure such knowledge is transmitted to the next generation and used as a teaching tool in educational institutions.

This paper is also a reference point for the government and the educational sector to understand the importance of preserving cultural heritage and how policies can further support the Nigerian film industry in playing this role. The Nigerian government has a role to play by partnering with the Nigerian film industry in the provision of funds and training to encourage filmmaking in Nigeria.

For future research, researchers can focus on a particular area of culture such as the use of proverbs and the role that film can play in preserving such cultural heritages. Movies revolving around such historical figures and cultural values can also be better explored by the Nigerian film industry, as research reveals that foreign movies such as Thor and Wonder Woman revolving around fictional myths and legends have collectables such as figurines, $\mathrm{t}$-shirts, accessories amongst others that can be purchased by a wide range of audience including children and adults. These additional efforts further help in sparking a cultural revolution among the audience, who can almost relate to the legends as personal super-heroes.

\section{Acknowledgements}

Special thanks to Dr Silk Ugwu Ogbu who facilitated the course that led to the development of this paper.

\section{References}

76 The Movie. (2015). The Synopsis. Retrieved February 20, 2020, from 76 The Movie: http://76themovie.com/ Adeeko, A. (2017). Akinwumi Isola's Efunsetan Aniwura and Yoruba woman-being. In A. Adeeko, Arts of being Yoruba. Divination, allegory, tragedy, proverb, panegyric (pp. 95 - 119). Ibadan: Book Craft.

Ademuleya, B. (2017). Textiles and dresses. In T. Falola, \& A. Akinyemi (Eds.), Culture and customs of the Yoruba (pp. 281-294). Austin: Pan African University Press.

Adeoye, A. (2016). Efunsetan Aniwura: Yoruba's most powerful woman that ever lived? Retrieved February

21, 2020, from The News Nigeria: HYPERLINK "https://www.thenewsnigeria.com.ng/2016/12/efunsetananiwura-yorubas-most-powerful-woman-that-ever-lived/"

https://www.thenewsnigeria.com.ng/2016/12/efunsetan-aniwura-yorubas-most-powerful-woman-that-everlived/

Afolabi, O. (2011). "Nollywood" Yoruba film project. Yoruba films by Tunde Kelani: Primary cultural and linguistic data collection. Austin: COERLL.

Agai, J. M. (2015). Rethinking Yoruba culture in the light of Yoruba origins. Journal for Semitics, 24(2), 427450.

Agai, J. M. (2021). Reflection on the theory of the Arab origin of the Yoruba people. Theologia Viatorum, 1-9.

Agbanusi, A. (2017). How colonialism underdeveloped Nigerian indigenous languages. Mgbakoigba, Journal of African Studies, 7(1), 150-155.

Akanji, O. R., \& Dada, O. M. (2012). Socio-historical crime review on Efunsetan Aniwura, Bashorun Gaa and Aare-Ago Ogunrinde Aje. The Journal of International Social Research, 5(2), 404-412.

Akinseye, I. (2017). Movie review: Hits and misses of Kemi Adetiba's the wedding party. Retrieved March 2 , 2020, from Vanguard Nigeria: https:/www.vanguardngr.com/2017/04/movie-review-hits-misses-kemiadetibas-wedding-party/

Akintoye, S. A. (2014). The Beginnings. In S. A. Akintoye, A history of the Yoruba people (pp. 18-35 Dakar: Amalion Publishing.

Alao, A. (2017). Politics and government. In T. Falola, \& A. Akinyemi (Eds.), Culture and customs of the Yoruba (pp. 595-605). Austin: Pan-African University Press.

Ani, K. J. (2012). UNESCO prediction on the extinction of Igbo language in 2025: Analyzing societal violence and new transformative strategies. Developing Country Studies, 110-118.

Baecker, D. (1997). The meaning of culture. Thesis Eleven, 51(1), 37-51.

Balabantaray, S. R. (2020). Impact of Indian cinema on culture and creation of world view among youth: A sociological analysis of Bollywood movies. Journal of Public Affairs, 1 - 7.

Carter-Enyi, A. (2018). "Lùlù fún wọn": Oríkì in contemporary culture. Ethnomusicology, 62(1), 82-102.

Dalton, S. (2016, September 17). '76': Film Review. TIFF 2016. Retrieved May 5, 2021, from Hollywood Reporter: https:/www.hollywoodreporter.com/movies/movie-reviews/76-review-929856/

Enahora, A.-U. (1989). Film Makers and Film Making in Nigeria: Problems and Prospects. African Media Review, 98-109. Retrieved April $\quad 20, \quad 2017, \quad$ from http://pdfproc.lib.msu.edu/?file=/DMC/African\%20Journals/pdfs/africa\%20media\%20review/vol3no3/jamr 003003008.pdf 
Hasibuan, Z. A., K.Isal, Y., N.C., B. A., Ahmad, M., \& Selviandro, N. (2011). Preservation of cultural heritage and natural history. International Journal of Machine Learning and Computing, 1(5), 460-465.

Ilesanmi, O. O. (2014). Efunsetan Aniwura: A Psycho-historical exploration of women's psychopathology. International Journal of Information and Education Technology, 4(2), 147-150.

Izuzu, C. (2016, April 7). Who remembers Tunde Kelani's 1997 movie "Oleku?". Retrieved April 28th,2017, from Pulse Ng: HYPERLINK "http://pulse.ng/movies/throwbackthursday-who-remembers-tunde-kelanis1997-movie-oleku-id4892533.html" http://pulse.ng/movies/throwbackthursday-who-remembers-tundekelanis-1997-movie-oleku-id4892533.html

Johnson, M. T. (2013). What is culture? What does it do? What should it do? In M. T. Johnson, Evaluating Culture (pp. 97-119). London: Palgrave Macmillan.

Leroy, F., Olaleye-Oruene, T., Koeppen-Schomeru, G., \& Bryan, E. (2002). Yoruba customs and beliefs pertaining to twins. Twin Research, 5(2), $132-136$.

Maisuwong, W. (2012). The promotion of American culture through Hollywood movies to the world. International Journal of Engineering Research \& Technology (IJERT), 1(4), 1-7.

Mckenzie, J.-M. (2018). "Coming to America: turns 30: Creators break down the film's most iconic scenes. Retrieved February 20, 2020, from Good Morning America:

https://www.goodmorningamerica.com/culture/story/coming-america-turns-30-creators-break-films-iconic 55903734

Odejimi, S. (2018). Akinwunmi Isola: The "honest" man who will be remembered for classics "Efunsetan Aniwura" and "Oleku". Retrieved from April 2, 2020, The Net: http://thenet.ng/akinwunmi-isola-honestman-will-remembered-classics-efunsetan-aniwura-oleku/

Onyima, B. N. (2016). Nigerian cultural heritage: preservation, challenges and prospects. Ogirisi: A new journal of African studies, 12, 273-292.

Ogunleye, F. (2004). A male-centric modification of history: "Efunsetan Aniwura" revisited. History in Africa, 31, $303-318$.

Olaiya, T. A. (2020). Narrative of governance crisis in Nigeria: Allegory of resource curse and "Emergence" in Tunde Kelani"s Saworoide and Agogo-Eewo. Cogent Social Sciences, 6, 1-24.

Olajoke, A. S., \& Oluwapelumi, A. M. (2018). A study on the extinction of indigenous languages in Nigeria: Causes and possible solutions. Annals of Language and Literature, 2(1), 22-26.

Olaoye, A. A., \& Bello, Y. (2016). Nigerian dress culture: An anthropo-linguistic communication tool. Nile Journal of English Studies, 2(2), 12-17.

Olowookere, P. O. (2016). The Yoruba clothing culture, its form and content. Journal of Pristine, 12(1), $120-132$.

Olutayo, A. O., \& Akanle, O. (2009). Aso-oke (Yoruba's hand woven textiles) usage among the youths in Lagos, Southwestern Nigeria. International Journal of Sociology and Anthropology, 1(3), 62-69.

Omoera, O. S. (2015). The Invasion 1897 agenda in the Benin language film segment of Nollywood. EJOTMAS Ekpoma Journal of Theatre and Media Arts, 5(1/2), 303-311.

Osoba, J. (2014). The nature, form and functions of Yoruba proverbs: A socio-pragmatic perspective. IOSR Journal of Humanities and Social Sciences, 19(2), 44-56.

Oti, A., \& Ayeni, O. (2013). Yoruba culture of Nigeria: Creating space for an endangered specie. Cross-cultural communication, 9(4), 23-29.

Oza, P. (2020 - 2021). Film as a tool for war propaganda: Synopsis from World War I. The Journal of Indian Art History Congress, 26(2).

Sherak, T. (2011, June 19). The Role of Film in Society. (V. Shah, Interviewer) Retrieved April 27th, 2017, from Thought Economics: https://thoughteconomics.com/the-role-of-film-in-society/

Showkat, N. (2017). Media \& Culture: A theoretical perspective of the inter-relationship. National Journal of Multidisciplinary Research and Development, 2(1), 55-60.

Teutsch, M. (1995). "I think Aladdin looked kinda white”: Teaching Cultural Projection in the Classroom.

Retrieved April 28, 2017, from Teaching Pals: https://teachingpals.wordpress.com/tag/cultural-projection/

Tsebee, K. A. (2011). The role of the mass media in promoting the Nigerian cultural heritage. Journal of Communication and Culture: International Perspective, 26-35. Retrieved April 20, 2017, from https:/www.icidr.org/doc/ICIDR\%20PDF\%20contents/journal\%20of\%20research\%20in\%20education\%20 and $\% 20$ society/JRESSvol2\%20nos3\%20december $\% 202011 /$ the $\% 20$ role $\% 20$ of $\% 20$ the $\% 20$ mass $\% 20$ media $\% 20$ in $\% 20$ the $\% 20$ prevention.pdf

Weinstein, P. B. (2001). Movies as the gateway to history: The history and film project. The History Teacher, $35(1), 27-48$. 